\title{
Community Empowerment through Processed Diversification and Marketing Strategy of the Wanita Gemari Polkahsar in Pemalang District
}

\author{
Nayu Nurmalia ${ }^{1}$, Tatty Yuniarti ${ }^{1, *}$, and Mauliddyane Zidhane ${ }^{1}$ \\ ${ }^{1}$ Department of Fisheries Extention, Jakarta Technical University of Fisheries, Cikaret Street No.2, \\ Bogor 16132, West Java, Indonesia
}

\begin{abstract}
Pemalang is one of the sub-districts in the Pemalang district which has considerable fishery potential. One area of business is the processing of fisheries. Products in each group vary, such a fish thrown, salted fish, fish cake, and fish chips. Identifying the problem hasn't added to the variety of fisheries processing products. Packaging is less attractive. The purpose of research is to increase knowledge, skill, and attitude through outsourcing activities about product diversification and the marketing strategy. The study was carried out on $2^{\text {nd }}$ March -15 Mei 2020. Counseling methods with group meetings, demonstrations of tutorials, lectures, and group discussion with the aim of Wanita Gemari Poklahsar. Counseling activities include (1) diversification of processed fish, (2) marketing strategy through packaging designs, and (3) counseling about online marketing. The T-test conducted with SPSS shows a significant value of 0,000 , which indicates that the counseling activities have a substantial effect on improving the aspects of respondents' knowledge, skills, and attitudes.
\end{abstract}

\section{Introduction}

Pemalang is one of the sub-districts in the Pemalang regency that has considerable fishery potential. The area of the Pemalang subdistrict is 10,193 ha and consists of 20 villages and villages bordering the Java Sea in the north, Randudongkal and Bantarbolang subdistricts to the south, Tegal Regency to the west, and Taman Subdistrict to the east [1]. The potential of developing fisheries in the field of fishery processing business conducted by fishery processing groups.

Pemalang sub-district has 54 fishery households $(R T P)$ that strive in the field of fish processing. The $R T P$ is divided into seven processing groups. The types of processed fish produced in general do not vary. Processed fish products include fish crackers, pindang, and salted fish [2]. The result of the identification of processing group problems in this preliminary study is the limited variety of processed fish products caused by the fishery households is the little variety of processed fish products. The cause of the problem was that the fishery households didn't yet know the variation of fishery processing products. The

\footnotetext{
* Corresponding author: tatty.yuni@gmail.com
} 
ability to make varied products through the right technology can be used to increase the income of the fishery households [3] by the fishery households didn't yet know the variation of fishery processing products. The ability to make varied products through the right technology can be used to increase the income of fishery households [3].

Another problem is that the way of packaging processed fish products is still simple. This simple packaging causes consumers to be less interested in processed products of fish processing groups in the Pemalang district. This results in the selling price of the product to below. Products with attractive packaging will cause enough sensory stimulation to be noticed and remembered by consumers to be interested in buying products [4]. Product packaging is very influential on the selling value of products because the packaging is a way to increase the company's profit. Packaging should be made as attractive as possible is expected to attract and attract the attention of consumers. In addition, packaging can also reduce damage to goods and ease the delivery process [5].

Marketing of processed fish products produced by fish processors in the Pemalang subdistrict still uses conventional means. The strategy that can be done by small and medium enterprises (SMEs) to increase revenue is to expand the marketing network, maintain quality, and improve sales services and increase cooperation with relevant agencies and other cooperatives to gain access to raw materials [6]. Counseling can improve target insights to market products produced online through the use of electronic media or the internet. Processed products made can reach a wider market at a low cost, and partners have a media promotion of various processed fish products in the form of brochures or leaflets, promotional $\mathrm{CDs}$, and websites. Online marketing impacts the well-being of families targeted at counseling [7]. The research aim was to improve knowledge, skills, and attitudes through product diversification and marketing strategies of fish processing groups (Wanita Gemari Poklahsar) in the Pemalang district through counseling.

\section{Materials and methods}

The research was conducted from March 2, 2020, to May 15, 2020. The research location is in Pemalang District, Pemalang Regency, Central Java Province. The research location was chosen purposively because it was close to the source of fish raw materials at fish landing site Tanjung Sari and the Fisheries Service of Pemalang Regency. Research respondents are ten members of the processing and marketing group (Poklahsar) for Wanita Gemari in Pemalang District.

Data on natural resources and human resources of fisheries obtained from (a) Central Bureau of Statistics (BPS), (b) office of the Fisheries Office of Pemalang Regency (c) Work Plan of Fishery Extension, and (d) study of literature and internet. The methods used in this study are group and individual approaches, including demonstration of how to diversify processed fish, marketing strategies through packaging design, online marketing. The group chairman's house conducts counseling on the diversification of processed fish, marketing strategies through packaging design, and online marketing.

The extension media are folders and booklets given to respondents, namely members of the Wanita Gemari Poklahsar. The respondents were members of the Wanita Gemari Poklahsar of 10 members. Responses from respondents to determine the increase in knowledge, attitudes, and skills of respondents were evaluated using a questionnaire for initial evaluation (pre-test) and final evaluation (post-test). Data retrieval techniques are conducted with interviews, observations, and documentation. The evaluation result has calculated the value of the change by finding the difference from the initial evaluation or pretest activities and the final evaluation or post-test so that the value of the change is obtained. 
Evaluation of the impact of counseling includes the stage of adoption of innovation, the details of the review of the stage of innovation adoption is (1) awareness stage, where the respondent begins to become aware of the innovations offered by the extension worker, (2) interest stage is be marked by her desire to ask or know more about everything related to the innovation suggested by the extension, (3) the assessing stage is the stage carried out by the respondent after considering the benefits obtained when applying the extension material, (4) the trying stage is the respondent tries on a small scale to be more confident in his assessment before applying it to a broader scale, (5) adoption or applying with confidence based on assessments and trials that have been conducted or observed by themselves [8]. Analysis of the data using SPSS version 23 to determine changes in the implementation of counseling on changes in the level of knowledge, skills, and attitudes of the target.

\section{Results}

\subsection{Characteristics of respondents}

Pemalang District is one of the sub-districts in Pemalang Regency, Central Java Province. The boundaries of the territory are marked with gates and stakes. The types of village boundaries on land can be in the form of natural boundaries or artificial boundaries. Artificial boundaries are man-made elements such as boundary pillars, roads, railways, irrigation canals, and so on, which are declared or set as village boundaries [9].

The research respondents were members of the Wanita Gemari Poklahsar of 10 people. The internal characteristics of the respondents, including age, education level, and business experiences, can be seen in Table 1 .

Table 1. Age, education level, and business experience of respondents.

\begin{tabular}{|c|c|c|}
\hline \multicolumn{3}{|c|}{ Age } \\
\hline Categories & Standard (years) & amount (respondents) \\
\hline Young & $\leq 39$ & 2 \\
\hline Middle & $39>x \leq 48$ & 5 \\
\hline Old & $>48$ & 3 \\
\hline \multicolumn{2}{|c|}{ Amount } & 10 \\
\hline \multicolumn{3}{|c|}{ *Education Level } \\
\hline Categories & Standard & amount (respondents) \\
\hline low & $\leq 2$ & 4 \\
\hline middle & $2>x \leq 3$ & 5 \\
\hline high & $>3$ & 1 \\
\hline \multicolumn{2}{|c|}{ Amount } & 10 \\
\hline \multicolumn{3}{|c|}{ Business Experience } \\
\hline Categories & Standard (years) & amount (respondents) \\
\hline new & $\leq 2$ & 3 \\
\hline middle & $2>x \leq 4$ & 6 \\
\hline long & $>4$ & 1 \\
\hline
\end{tabular}


Amount

10

*Education leveal: 0 = No education; $1=$ primary school; 2 = Junior high school; 3 = Senior High

School; $4=$ undergraduate; $5=$ post graduate; $6=$ Doctoral

\subsection{Counseling on diversification of processed fish}

Counseling with diversified fish processing materials aims to improve the target's knowledge, attitudes, and skills in making innovations made from fish, namely amplang crackers. The material given is emphasized on; (1) how to file fish, (2) maintain the freshness of fish by using ice during processing, (3) apply suitable production methods by applying cleanliness of tools, materials, and self (4) procedure for making amplang crackers. In the extension activities with the diversification of processed fish material, pre-test and post-test were carried out to measure changes in respondents' level of knowledge and attitudes. The results of the pre-test and post-test are shown in Fig. 1.

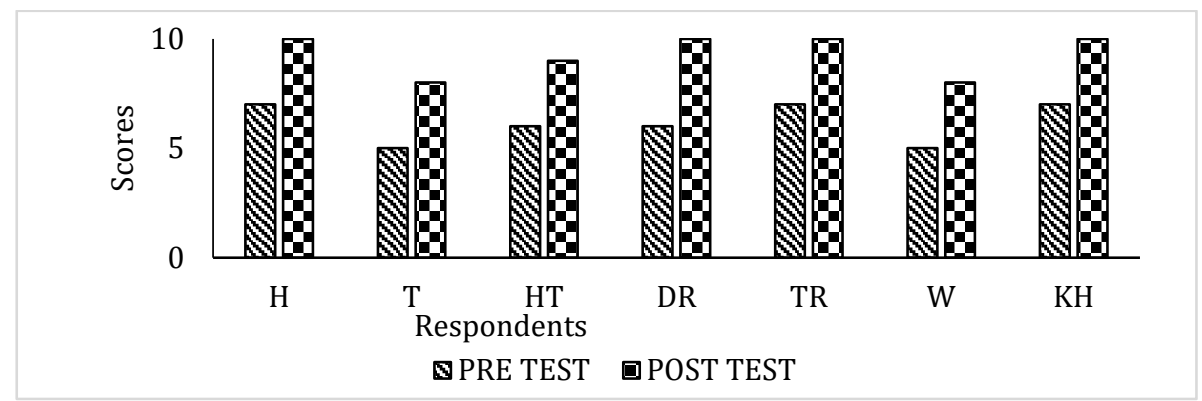

Fig. 1. Evaluation of changes in respondent's knowledge.

(H, T, HT, DR, TR, KH, UA is a member of the Wanita Gemari Poklahsar)

The data were analyzed by using the paired T-test or the comparison test of two paired data. The average result of the pre-test score is 6.14, and the average post-test score is 9.29. The number of respondents was as many as 7 people. There is a significant average difference of 3.15 points.

The results of the paired samples test obtained the value of sig. (2-tailed) of $0.000<0.05$. This value states that there is a significant difference between the results of the pre-test and post-test. This means that there is an influence from the extension on demonstrations of how to make amplang crackers. Meanwhile, to measure the attitude aspect of the main actors, it is shown in Fig. 2.

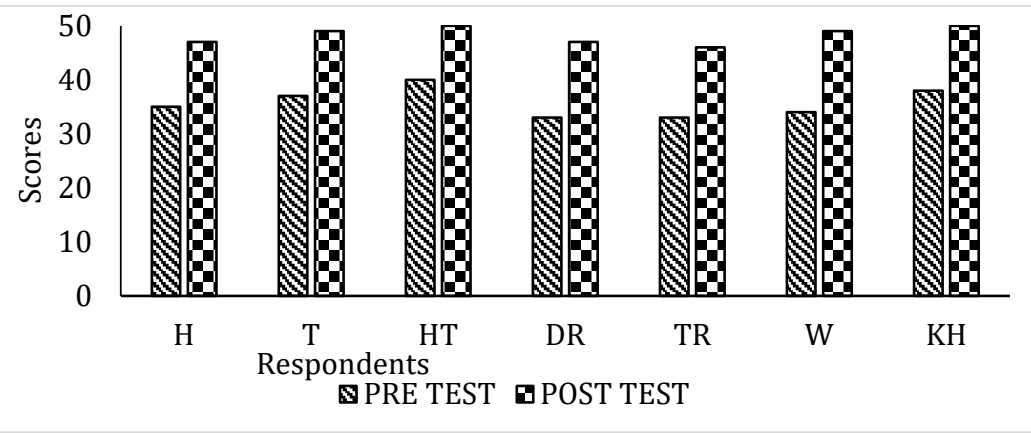

Fig. 2. The results of the evaluation of the attitude aspect.

(H, T, HT, DR, TR, KH, UA is a member of the Wanita Gemari Poklahsar) 
The data from the evaluation on the attitude aspect were then analyzed using a paired Ttest or the comparison test of two paired data. The average result of the pre-test score is 35.71, and the average post-test score is 48.29 . there is a significant average difference between the pre-test and post-test results, which is 12.58 points. This shows that there is an increase in the attitude aspect of the respondents. Paired samples test was carried out to determine the effect of counseling action activities on increasing respondents' attitudes.

Paired samples test on the value of sig. (2-tailed) of $0.000<0.05$, indicating that there is a significant difference between the results of the pre-test and post-test. This means that there is an influence from outreach activities regarding demonstrations on how to make amplang crackers. Changes as a result of the learning process can be shown in various forms, such as changing knowledge, skills and abilities, reaction power, acceptance power, and other aspects that exist in individuals [15]. Furthermore, the recapitulation results of the evaluation of the diversification skills aspect of processed fish at the Wanita Gemari Poklashsar are presented in Fig. 3.

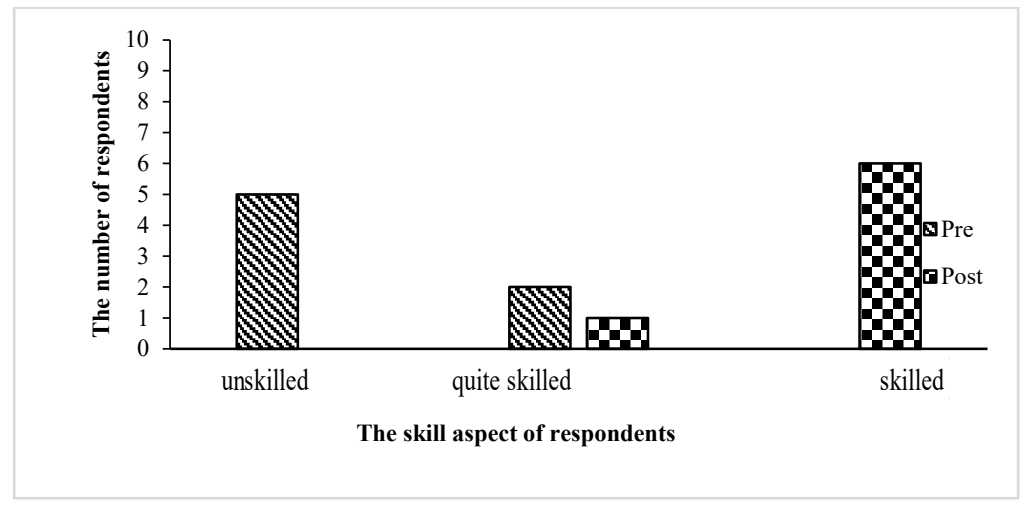

Fig. 3. The results of the evaluation of the skills aspect.

The evaluation of innovation adoption was carried out by observing respondents through WhatsApp online media because of conditions that did not allow follow directly the level of acceptance and application of respondents to the material or innovations submitted regarding the application of making amplang crackers. Data on the adoption of respondent's innovations for counseling demonstrations on making amplang crackers are shown in Fig. 4.

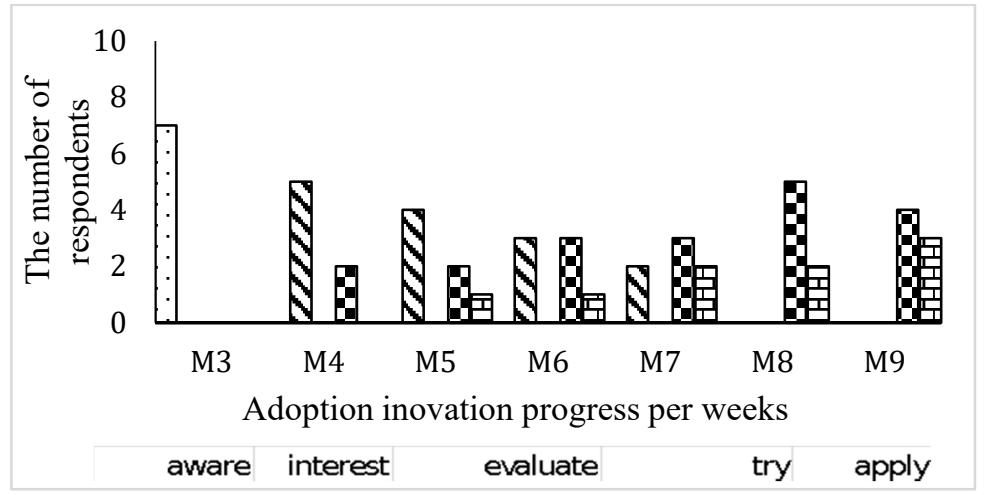

Fig. 4. Adoption of processed fish diversification innovation.

( $\mathrm{M} 1=$ week $1 ; \mathrm{M} 3=$ week 3; M4=week 4, M5= week 5; M6= week $6 ; \mathrm{M} 7=$ week 7; M8= week 8; M9= week 9) 


\subsection{Results of marketing strategy counseling through packaging design}

Counseling on marketing strategies through packaging design aims to increase knowledge, attitudes, and adoption innovation towards packaging processed products produced by the Wanita Gemari Poklahsar [18] argues that marketers are ultimately responsible for defining the characteristics that differentiate them their products and providing clear contrasts between products. So that the product packaging design can give clear and specific information to consumers, and one point of comparison, a purchase has been motivated. Evaluation of counseling using pre-test and post-test to measure respondents' level of knowledge to the material provided is shown in Fig. 5.

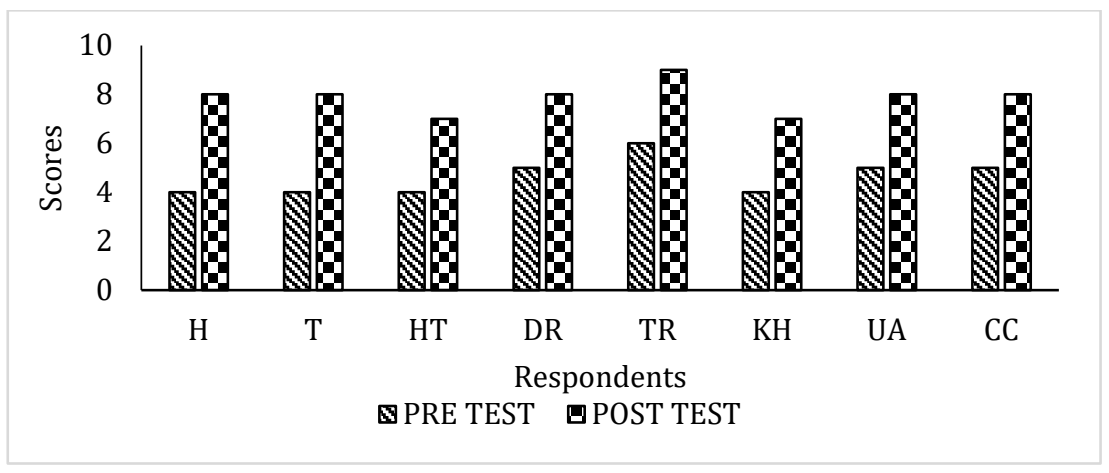

Fig. 5. The results of the evaluation of the knowledge aspect.

(H, T, HT, DR, TR, KH, UA is a member of the Wanita Gemari Poklahsar)

The evaluation results of the knowledge aspect were then analyzed using a paired T-test or a comparison/difference test of two paired data. The results of the paired T-test analysis. The results of the knowledge evaluation were conducted on eight respondents with an average pre-test score of 4.63 and an average post-test score of 7.88. There is a significant average difference between the results pre-test and post-test. The average difference is equal to 3.25 points. This shows that there is an increase in understanding of the knowledge aspect of the respondents. Paired samples test was carried out to determine the effect of extension action activities on increasing respondents' knowledge.

Evaluation of the attitude aspect of respondents/main actors towards counseling regarding packaging design is shown in Fig. 6.

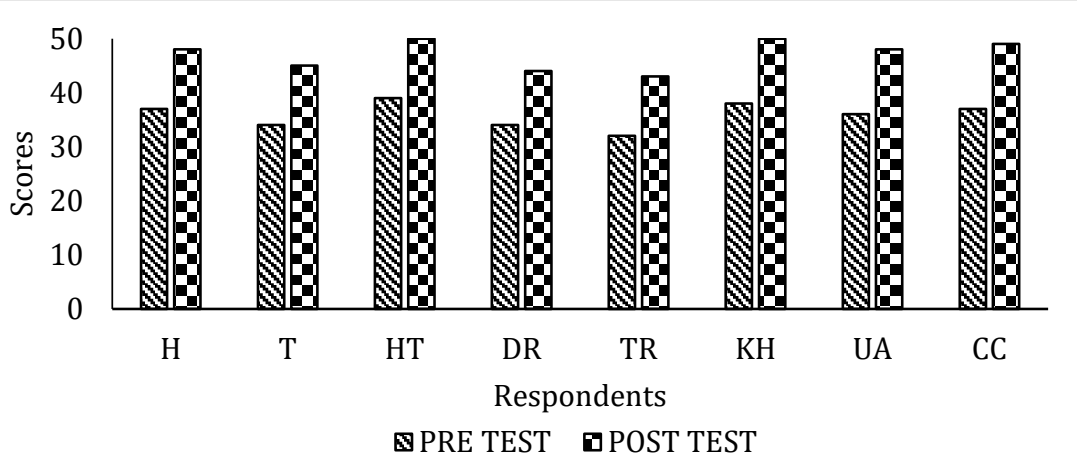

Fig. 6. The results of the evaluation of the attitude aspect.

$(\mathrm{H}, \mathrm{T}, \mathrm{HT}, \mathrm{DR}, \mathrm{TR}, \mathrm{KH}, \mathrm{UA}$ is a member of the Wanita Gemari Poklahsar) 
Attitude is a way of reacting to a stimulus that comes from the surroundings, either from people, objects, or situations that affect it [16]. Based on the graph in Fig. 6, the attitude aspect of respondents in counseling about marketing strategies through packaging design has increased significantly. The data from the evaluation of the attitude aspect was then analyzed using a paired T-test or a comparison test of two paired data. Paired samples test determined the extension activities' effect on increasing respondents' attitudes.

Evaluation of innovation adoption was carried out by observing respondents through WhatsApp online media, namely monitoring the level of acceptance and application of respondents to the innovative material that has been submitted regarding the application of the use of packaging label designs. Data on the adoption of respondents' innovations for counseling about packaging label design is shown in Fig. 7.

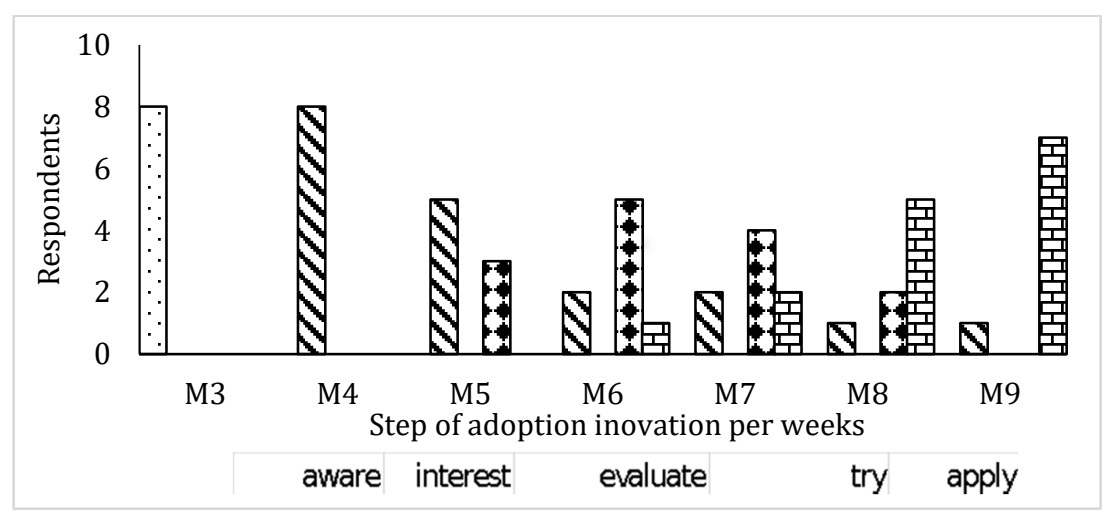

Fig. 7. Adoption of innovations on counseling on packaging design ( $M 1=$ week $1 ; M 3=$ week 3 ; M4=week 4, M5= week 5; M6= week 6; M7= week 7; M8= week 8; M9= week 9).

Based on Fig. 7, there is an increase in the adoption stage every week. In the $3^{\text {rd }}$ week, the respondents were in the conscious stage. In the $4^{\text {th }}$ week, some respondents had reached the interest stage. In the 5th week, there were respondents already at the stage of trying to identify the processed product so that information about the product could be listed on the packaging label following the requirements that must be listed on the packaging label. In weeks 5 to 9 , there were already respondents who applied appropriate packaging designs in their business activities.

\subsection{Results of online marketing counseling}

Evaluation of the results of the extension is used to measure respondents' level of knowledge and attitudes to the material provided. Knowledge gained through his perception of the stimulus by using the senses. The result of perception in the form of information will be stored in the memory system to be processed and given meaning. Then the information is used (retrieved) when needed [21]. The results of the evaluation of counseling about online marketing on the knowledge aspect of the respondents are shown in Fig. 8. 


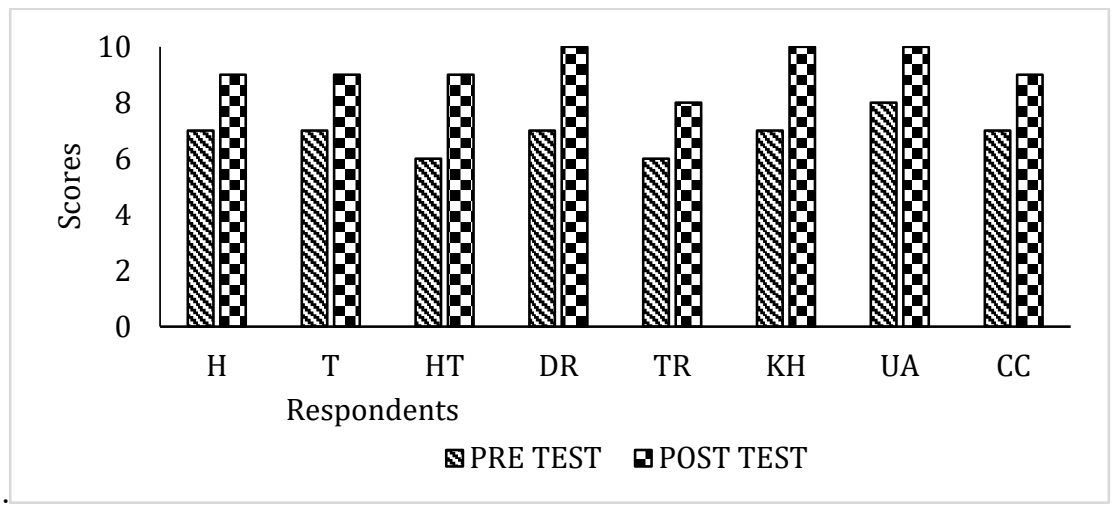

Fig. 8. The results of the evaluation of the knowledge aspect.

(H, T, HT, DR, TR, KH, UA is a member of the Wanita Gemari Poklahsar)

Based on Fig. 8, there was a significant increase in the extension activities' knowledge aspect. The evaluation results of the knowledge aspect were analyzed using a paired T-test or a comparison test of two paired data. The average effect of the evaluation of the knowledge of 8 respondents in Figure 8 shows a pre-test score of 6.88 and a post-test score of 9.25. That was concluded that there is a significant average difference is equal to 2.37 points. This shows that there is an increase in understanding of the knowledge aspect of the respondents. Paired samples test was conducted to determine the effect of extension action activities on increasing respondents' knowledge. Furthermore, the results of the attitude aspect assessment are shown in Fig. 9.

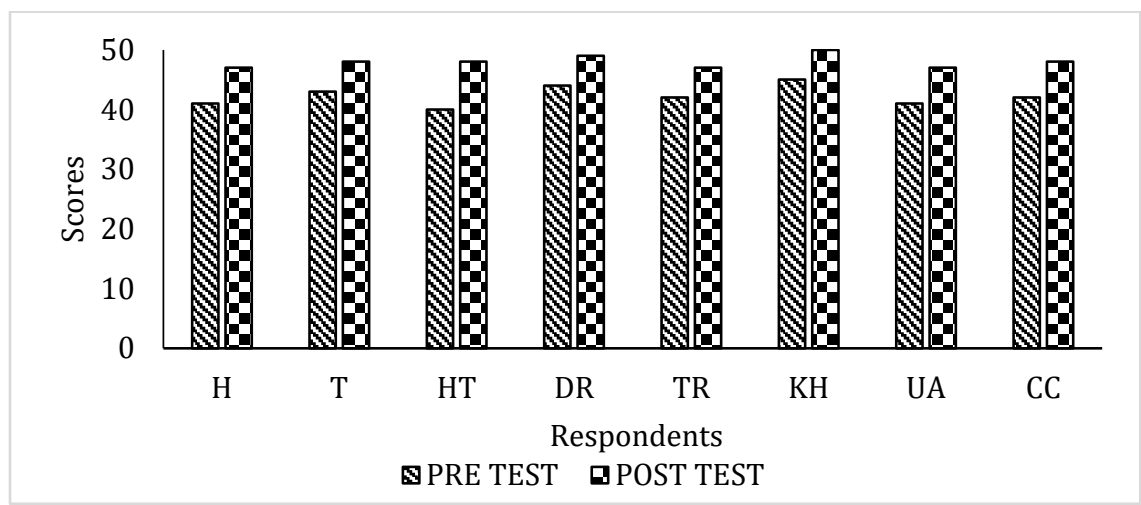

Fig. 9. The results of the evaluation of the attitude aspect.

(H, T, HT, DR, TR, KH, UA is a member of the Wanita Gemari Poklahsar)

The attitude evaluation scores of 9 respondents are the average pre-test scores of 42.25 and the post-test average value of 48.00 . It can be concluded that there is a significant difference between the pre-test and post-test scores to 6.25 points. This shows an increase in understanding of the knowledge aspect of the respondents (main actors). Paired samples test was to determine extension activities effects on increasing respondents' knowledge. Evaluation of respondents' adoption of innovation on online marketing counseling is shown in Fig. 10. 


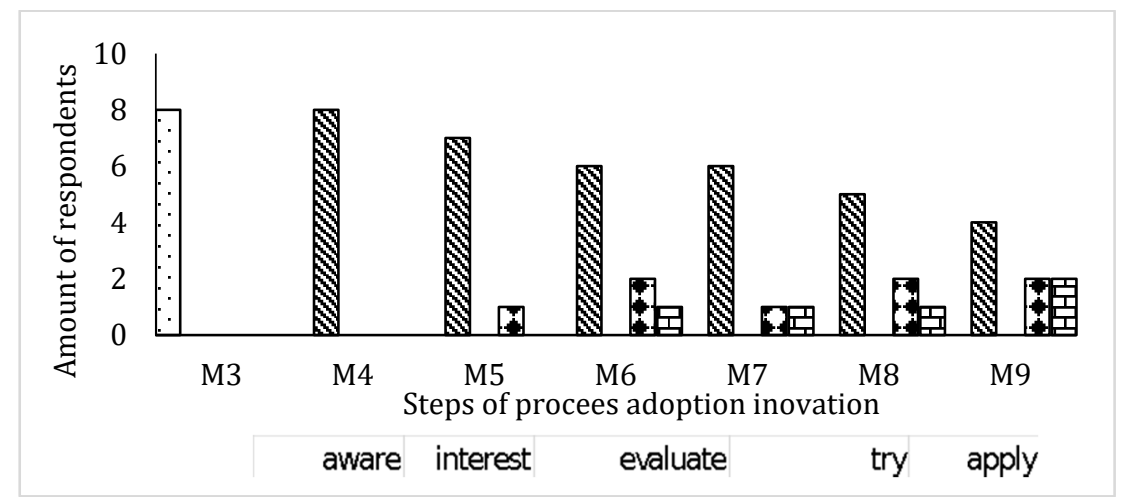

Fig. 10. Adoption of Innovation towards online marketing counseling. M3 = week 3; M4=week 4, M5= week 5; M6= week 6; M7= week 7; M8= week 8; M9= week 9)

Fig. 10. shows that there is an increase in the adoption stage per week. In the $3^{\text {rd }}$ week, the respondents were at the conscious stage. In the $4^{\text {th }}$ week, there were already respondents who reached the interest stage. In week five, some respondents are already in the trying stage. In weeks 7 to 9 , there are already respondents who apply appropriate marketing in their business activities.

\section{Discussion}

\subsection{Characteristics of respondents}

The characteristics of respondents can be seen in Table1. From the ten targets of people, two people are included in the young age category, five people in the middle age category, and three people in the old age category. The working population is the population aged 15 years and over. The population included in the productive age is the population in the age range of $15-65$ years. Populations not included in the effective age category are people aged $<15$ years and aged $>65$ years [10]. Based on observations in the field, the total respondents are included in the category of productive age, with the age range of respondents from 39 to 48 years.

The education level of the respondents consists of three groups, namely four people who are included in the category of low education, five people who are included in medium education, and one person is included in higher education. Factors that influence learning success include individual age, talent, learning capacity, learning objectives, level of aspirations, understanding of what will be known, and knowledge of success and failure [11].

There are three respondents' business experiences in the new category, six in the medium category, and one in the old type. The length of the business experiences can affect the level of income, and the length of the business will affect its productivity by ability or skills of businessman. The longer the work experience, the more understanding consumer tastes or behavior will be [12].

\subsection{Counseling on diversification of processed fish}

There was an increase in understanding of the knowledge aspect of the respondents, as shown in Fig. 1. Counseling on the diversification of processed fish uses the demonstration method 
with the aim that the counseling material can be absorbed by the target optimally because it can be understood through the senses of hearing, the senses of sight, and the active participation of respondents with direct practice. Counseling will increase the knowledge of respondents because it is supported by media that support the counseling process. According to the statement [13], the learning process will run effectively and efficiently if the supporting media support it. Participants will be more stimulated if media or facilities are provided that keep the interaction process. Paired samples test had been carried out to determine the effect of extension action activities on increasing respondents' knowledge.

Based on Fig. 2, there was an increase in the attitude aspect of respondents in outreach activities about fish processing diversification. There are three critical variables in the formation of attitudes: attention, understanding, and acceptance, which go through several stages in its implementation. The first stage is that the stimulus delivered will be answered by paying attention to the content of the stimulus. The second stage occurs a process of understanding the concept that is made, but if the concept is not understood, then the second stage cannot be achieved. The third stage is a reaction in the form of action, namely a change in attitude. This means that the stimulus had been received through the process of attention, understanding in the components of cognition and affection [14].

Fig. 3. shows that the demonstration activity of how to make amplang crackers improved the skills of the respondents. It can be seen that before the extension action was carried out, there were five respondents who were unskilled and two respondents were exceptionally skilled, and there was an increase in the skills of the respondents after the extension action was carried out, namely one person who was entirely professional and six skilled.

The performance of students in demonstrating their skills in doing something can be measured through observation techniques [16]. Counseling had been carried out using direct practical methods supported by other media such as print media in the form of leaflets, broadcast media, and direct media, which are expected to improve skills and can independently demonstrate the material given and process various kinds of processed fish independently. This agrees with the statement [13] that a person's knowledge is received through the senses, the most channeling ability into the brain is the sense of sight, approximately $75 \%$ to $87 \%$ of human knowledge is obtained through the sense of sight, $13 \%$ through the sense of hearing and another $12 \%$ is channeled through the other senses.

Based on the data in Fig. 4., there was an increase in the adoption stage, in the 1st-week respondents were aware of the importance of diversifying processed fish innovations. In the 4th week, there were respondents who were interested and tried to process amplang crackers, while in the 5th to 9th week they had there were respondents who applied the material to demonstration activities on how to use amplang crackers in their business/business activities. This is because of the enthusiasm of the respondents with the processed diversification material provided, the material was well-received, and there was good feedback from the demonstration activity on how to make this amplang cracker. The success of education is influenced by strategies and methods, and learning aids used in the educational process. For that, it needs to be designed effectively [17].

\subsection{Marketing strategy counseling through packaging design}

The evaluation of the knowledge aspect of marketing strategy counseling through packaging design in Fig. 5. was analyzed by the paired samples test returns the sig value. (2-tailed) of $0.000<0.05$. It can be interpreted that there is a significant difference in average between the pre-test and post-test results. That means there is an influence from the counseling action activities on packaging design that are carried out. It does not require persuasion to influence 
early recipients because they are always trying to find something that can benefit social or economic life [19].

Fig. 6. showed the attitude evaluation carried out on eight respondents was the result in an average pre-test score of 35.88 and an average post-test score of 47.13 . It was a significant difference between the pre-test and post-test scores, which is equal to 11.25 points. This shows that there is an increase in understanding of the knowledge aspect of the respondents. This agrees with [20], which states that without a change in attitude, increasing knowledge, and improving skills in training participants, the program can be said to be a failure. Paired samples test was to determine the extension activity's effect on increasing respondents' knowledge.

The paired samples test results in the value of sig. (2-tailed) of $0.000<0.05$. It can be interpreted that there is a significant difference in average between the pre-test and post-test results. It means that there is an influence from the extension action activities on packaging design. Change is a form of the result of the learning process. These changes can be shown in various forms such as increased knowledge, skills and abilities, reaction power, acceptance power, and other aspects that exist in individuals [15].

Fig. 7. shows in weeks 5 to 9 , there were already respondents who applied appropriate packaging designs in their business activities. Respondents are aware of the importance of packaging for their products because packaging will give an impression to consumers. The respondents' enthusiasm to change the packaging to be more attractive and informative increased through this outreach activity. This is in line with the statement [4] that packaging is one of the strategies used by companies to make products more attractive in terms of shape, color, product quality can be maintained. Currently, many companies are aware of creating beautiful product packaging. This is because the company uses the package at the same time for promotion.

\subsection{Online marketing counseling}

Fig. 8. shows that the results of the paired samples test. It can be concluded that the value of sig. (2-tailed) of $0.000<0.05$. There is a significant difference between the pre-test and posttest. It means that there is an influence from the extension activities on packaging design. Counseling is one way that can be done to increase knowledge/information for the community. Face-to-face counseling and providing information directly are expected to be more effective than counseling through mass media or leaflets [22].

Fig. 9. shows that the results of the paired samples test were the value of sig. (2-tailed) of $0.000<0.05$. There is a significant difference between the pre-test and post-test scores. It means that counseling action activities affect online marketing while measuring the attitude aspect of respondents/actors main. The significance value (2-tailed) $<0.05$ indicates a significant difference between the initial and final variables. This shows that there is a significant effect on the difference in the treatment given to each variable [23].

Fig. 10. shows in weeks 7 to 9 , there are already respondents who apply appropriate marketing in their business activities. The respondent's obstacle in the adoption stage of online marketing is that most of the respondents do not own a mobile phone personally, so it is difficult to understand how to use internet facilities. Still, the target realizes that online marketing is very supportive of product promotion in a wide range. This is in line with the statement that online marketing has several advantages: a wider reach, saving time, effort, and costs, easier processes, ease of supervision, ease of managing inventory control, and without space limits [24]. 


\section{Conclusion}

Counseling using the demonstration method carried out to groups of the Wanita Gemari Poklahsar who enjoy fish processing diversification, marketing strategies for fishery products through packaging design, and online marketing can improve the attitudes, knowledge, and skills of respondents. Counseling is essential for the main fishery actors to increase their self-capacity, which impacts their income and welfare.

There is a need for support and guidance by local extension workers in providing information on technological innovations and fish processing diversification innovations so that group business activities continue to develop. The need for assistance to groups regarding the application of technology needed to support product marketing with an online system.

\section{References}

1. Badan Pusat Statistik, Pemalang District in 2018 figures (in Bahasa Indonesia) (BPS, Jakarta, 2018)

2. M. Zidhane, T. Yuniarti, N. Nurmalia, JPPIK. 14, 1 (2019)

3. R. Budhiati, S. Mulyani, National Seminar on Sustainable Development of Rural Resources and Local Wisdom (in Bahasa Indonesia), 8 (2018)

4. T. Susetyarsi, J. Chem. Inf. Model 4, 3 (2012)

5. Y. Erlyana, Conference of Creative Industry: Sustainable Tourism Industry for Economic Development Universitas, 1079-1097 (2018)

6. E.S. Setiyorini, B.P. Noorachmat, M. Syamsun, Manaj. IKM. 13, 1 (2018)

7. S. Abdullah, L. Daud, Bunyamin, R.E. Purwanti, CIASTECH, 1309-1318 (2020)

8. E.M. Rogers, Diffusion of innovations in modul: knowledge and innovation management (4301-410) (Hohenheim University, Stuttgart, 2011)

9. S. Handoyo, Geospatial Asp. L. Bord. between Indones. Timor-Leste 13, 175-183 (2011)

10. Badan Pusat Statistik, Population census data (in Bahasa Indonesia) (BPS, Jakarta, 2020)

11. T. Mardikanto, Agricultural extension system (in Bahasa Indonesia) (UNS Press, Surakarta, 2014)

12. A.N. Priyandika, Undergraduate, Semarang (ID): Universitas Diponegoro Semarang, (2015)

13. A. Arsyad, Learning Media (in Bahasa Indonesia) (Raja Grafindo Persada, Jakarta 2006)

14. B. Endroyo, Tek. Sipil dan Perenc. 12, 111-120 (2010)

15. N. Sudjana, Ibrahim, Educational research and assessment (in Bahasa Indonesia) (Sinar Baru Algesindo, Bandung, 2004)

16. P.D.B.M.S.U. Subali, Evaluation of learning (process and product) (in Bahasa Indonesia) (Universitas Negeri Yogyakarta, Yogyakarta, 2014)

17. E. Purnomo, N. Pangarsa, K.B. Andri, K. Tuban, M. Saeri, J. Inov. dan Teknol. Pembelajaran 1, 2 (2015)

18. A.S. Muharam, Undergraduate, Semarang (ID): Universitas Diponegoro Semarang, (2011)

19. G. Sedana, dwijenAGRO 3, 1 (2012) 
20. E.P. Widoyoko, Evaluation of learning programs (in Bahasa Indonesia) (Universitas Muhammadiyah Purworejo, 2009)

21. K. Hamida, S. Zulaekah, Mutalazimah, Kesehat. Masy. 8, 1 (2012)

22. C. Wowiling, L.R. Goenawi, G. Citraningtyas, PHARMACON J. Ilm. Farm. - UNSRAT 2, 3 (2013)

23. Advernesia, How to test paired simple t-test with SPSS and examples (in Bahasa Indonesia). advernesia.com (2017)

24. I.A.N. Kartini et al., J. Abdikarya J. Karya Pengabdi. Dosen dan Mhs. 3, 2 (2019) 